Saudi Journal of Medicine

Abbreviated Key Title: Saudi J Med ISSN 2518-3389 (Print) |ISSN 2518-3397 (Online) Scholars Middle East Publishers, Dubai, United Arab Emirates

Journal homepage: https://saudijournals.com/sjm

Original Research Article

\title{
A Study of Serum Magnesium Profile in Type - 2 Diabetes Mellitus
}

\author{
Dr. Praveena Kumara*
}

Associate Professor, Department of General Medicine, Kanachur Institute of Medical Sciences, Mangalore-Thokkottu-Konaje University Rd, Kotekar Village, Deralakatte, Karnataka 575018, India

DOI: $10.36348 /$ sjm.2020.v05i04.005 $\quad$ | Received: 31.03.2020 | Accepted: 08.04.2020 | Published: 13.04 .2020

*Corresponding author: Dr. Praveena Kumara

\section{Abstract}

In India, the scenario is not different when compared to the world scenario. The best strategies are not able to prevent the complications suggesting that alternative treatment strategies are needed. Insulin-dependent uptake of glucose is reduced in magnesium deficiency. Magnesium supplementation improves glucose tolerance. So one such treatment strategy under research is supplementation of magnesium and its role in primary prevention of diabetes and slowing the progression of complications that is related to the dreaded disease. So before anything it is best to understand the profile of serum magnesium in type 2 Diabetes mellitus. So this study is dedicated for this above said cause.

Keywords: Diabetes, Magnesium, Balance, Serum Levels.

Copyright @ 2020: This is an open-access article distributed under the terms of the Creative Commons Attribution license which permits unrestricted use, distribution, and reproduction in any medium for non-commercial use (NonCommercial, or CC-BY-NC) provided the original author and source are credited.

\section{INTRODUCTION}

In India, the scenario is not different when compared to the world scenario. The best strategies are not able to prevent the complications suggesting that alternative treatment strategies are needed [4]. Serum hyperglycaemia resulting from defects in insulin secretion, insulin action (may be due to failure of complex insulin - receptor interaction) or both [1]. According to the International Diabetes Federation (IDF), diabetes has affected at least 300 million people worldwide, and this number is expected to reach 450 million by the year 2030 [2]. There are mainly two types of diabetes Type -1 and Type-2, the latter type of diabetes mellitus is the most common form of diabetes accounting for $90 \%$ of the cases [3]. Insulin-dependent uptake of glucose is reduced in magnesium deficiency. Magnesium supplementation improves glucose tolerance. Magnesium, is an essential mineral needed by human body [5], It is also the fourth most abundant cation in the human body [6]. Magnesium orally produces diarrhoea; but intravenously it produces CNS depression [7]. It is also the activator of many enzymes requiring ATP. Alkaline phosphatase, hexokinase, fructokinase, phosphofructokinase, adenyl cyclase, cAMP dependent kinases, etc. need magnesium [7]. It is believed to play a role in glucose homeostasis, insulin action, and the development of type 2 diabetes [8]. It may influence insulin secretion by interacting with cellular calcium homeostasis [9]. Magnesium can function as a mild, natural calcium antagonist. So the level of intracellular calcium is increased in $\mathrm{Mg}$ deficiency subjects. This increased intracellular calcium may compromise the insulin responsiveness of adipocytes and skeletal muscles leading to the development of insulin resistance [10]. Another study has also found that insulin deficiency or insulin resistance can affect the tubular absorption of $\mathrm{Mg}$, leading to hypomagnesaemia in diabetic subjects [11]. Thus, a vicious circle is formed by mutual influence between insulin resistance and hypomagnesaemia resulting in aggravation of insulin resistance [12]. $\mathrm{Mg}$ has been reported to possess antioxidant property [13].

The dietary recommendation (Recommended Dietary Allowances/RDA) for magnesium is 400 to 420 $\mathrm{mg}$ daily for adult men and 310 to $320 \mathrm{mg}$ daily for adult women [14].

So before anything it is best to understand the profile of serum magnesium in type 2 Diabetes melliyus. So this study is dedicated for this above said cause.

Aims and Objectives: To study the serum magnesium profile in Type 2 Diabetes Mellitus.

\section{MATERIALS AND METHODS}

- This study was done in the Department of General Medicine, from A J Institute of Medical Sciences

- This study was done in from April 2015 to March 2016. 
- One hundred subjects who were diagnosed to be diabetic were included for the study. They were compared with the normal 100 patients.

- The complete history was taken and the relevant data was looked upon and noted. The blood was collected and was sent to the Department of Biochemistry for Magnesium level analysis.

\section{Inclusion Criteria}

- Patients who are confirmed type -2 diabetics.

\section{Exclusion Criteria}

- Patients who were on magnesium supplementation.

\section{RESULTS}

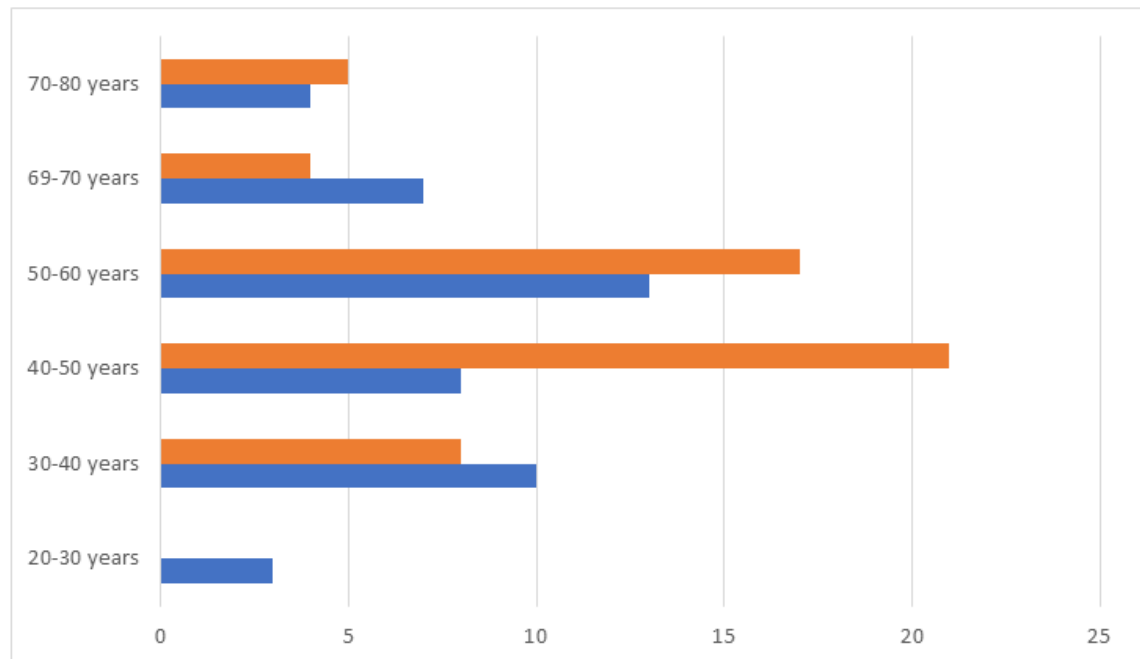

Fig-1: Age Distribution

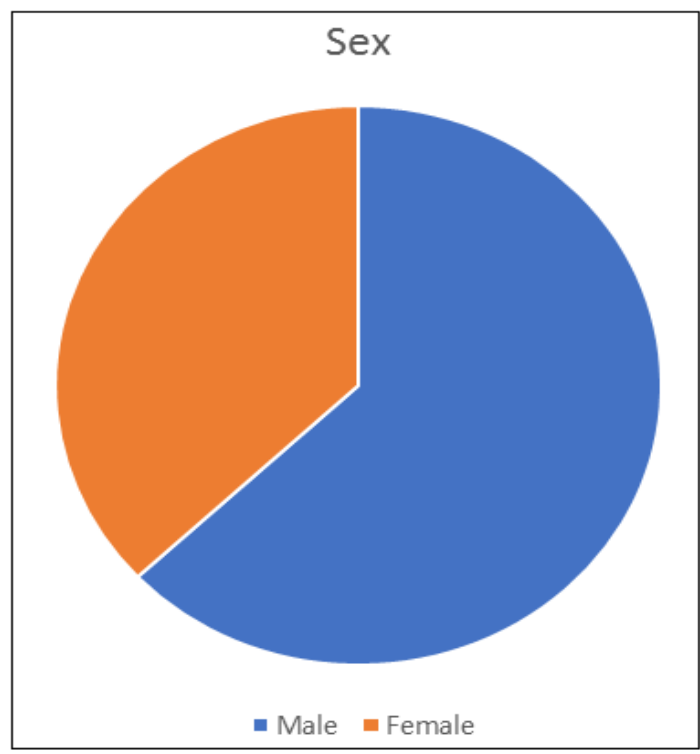

Fig-2: Gender Distribution

Table-1: Mean Magnesium levels

\begin{tabular}{|l|l|l|l|}
\hline & Normal & Diabetic & \multirow{2}{*}{ P VALUE } \\
\cline { 1 - 3 } & Mean \pm sd & Mean \pm sd & \\
\hline Mean Magnesium Levels & $2.14 \pm 0.76$ & $1.32 \pm 0.2$ & $<\mathbf{0 . 0 0 1}$ \\
\hline
\end{tabular}




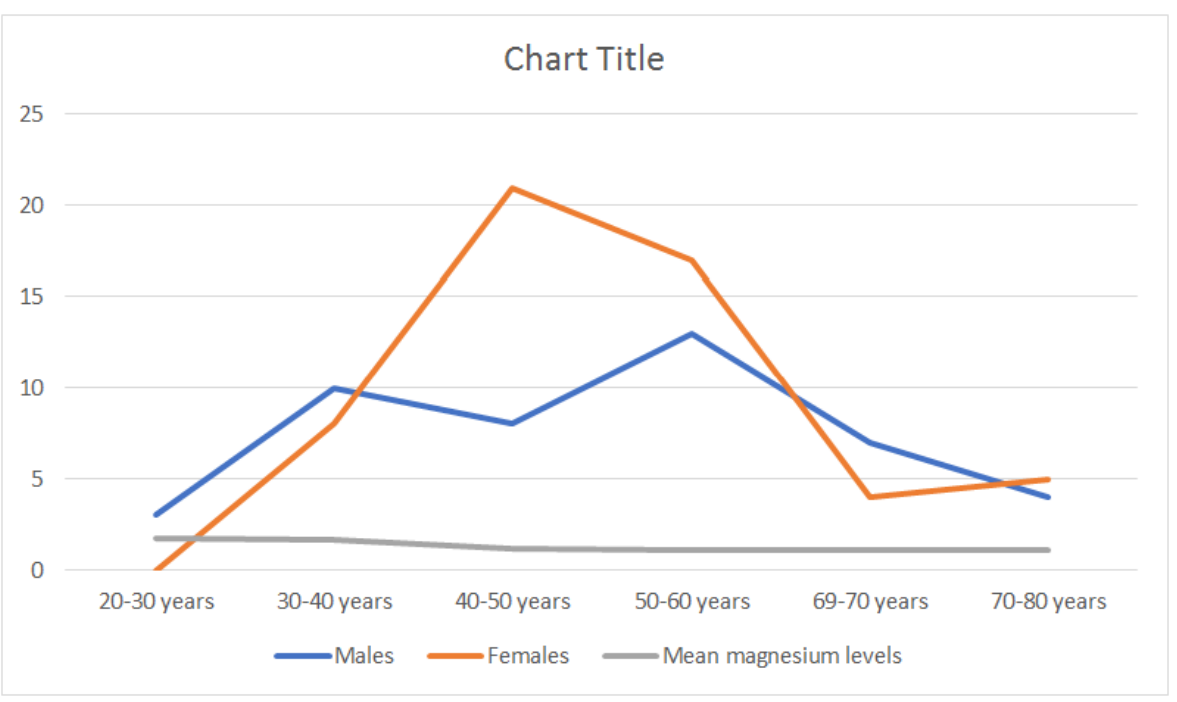

Fig-3: Mean serum magnesium levels

\section{DISCUSSION}

Hypomagnesemia in DM2 is present only in severe (and generally long lasting) $\mathrm{Mg}$ deficits. $\mathrm{A}$ chronic latent $\mathrm{Mg}$ deficiency without alteration in serum total $\mathrm{Mg}$ is more commonly observed [12]. These often undetected $\mathrm{Mg}$ insufficiencies have clinical importance, since $\mathrm{Mg}$ is a main co-factor in numerous enzymatic reactions (> 300 enzymatic reactions including all the enzymes of glycolysis). $\mathrm{Mg}$ also is deeply involved in the regulation of insulin signaling, in the phosphorylation of insulin receptor kinase, in the post receptorial action of insulin, and in insulinmediated cellular glucose uptake.

The clinical consequence of a chronic $\mathrm{Mg}$ deficit is post-receptorial insulin resistance and consequent reduced glucose utilization in the cells, worsening the reduced insulin sensitivity present in DM2.

Another possible link between $\mathrm{Mg}$ deficiency and reduced insulin sensitivity is the presence of oxidative stress and/or inflammation. Thus, free radicals are often increased in DM2, hypertension, metabolic syndrome and aging, conditions also associated with $\mathrm{Mg}$ deficits. In particular, we demonstrated an age-dependent deficit of cellular $\mathrm{Mg}$ in persons aged 65 years and over, as well as in patients with essential hypertension or DM2, independently of age.

Nevertheless, independently of the mechanisms of $\mathrm{Mg}$ deficits in DM2, metabolic syndrome, essential hypertension and aging, it is apparent that this $\mathrm{Mg}$ deficiency may contribute to enhance the insulin resistance status of these conditions. $\mathrm{Mg}$ deficit could precede and cause post-receptorial resistance of insulin and alter glucose tolerance.

\section{CONCLUSION}

Magnesium levels in diabetes is deranged and it has to be replenished which is ideal for the treatment of Diabetes Mellitus.

\section{REFERENCES}

1. Khodeir, S. A., Abd El Raouf, Y. M., Amer, A. E., El Fadaly, N. H., \& Abd El Latif, E. A. (2012). Paraoxonase gene polymorphism and activity in type 2 diabetes mellitus with microvascular complications. J Am Sci, 8(1), 531-537.

2. Xu, J., Zhou, Q., Liu, G., Tan, Y., \& Cai, L. (2013). Analysis of serum and urinal copper and zinc in Chinese northeast population with the prediabetes or diabetes with and without complications. Oxidative medicine and cellular longevity, 2013.

3. Prajna, K., Kumar, A., Rai, S., Shetty, S. K., Rai, T., Shrinidhi, M. B., \& Shashikala, M. D. (2013). Predictive value of serum sialic acid in type-2 diabetes mellitus and its complication (nephropathy). Journal of clinical and diagnostic research: JCDR, 7(11), 2435-2437.

4. Johansen, J. S., Harris, A. K., Rychly, D. J., \& Ergul, A. (2005). Oxidative stress and the use of antioxidants in diabetes: linking basic science to clinical practice. Cardiovascular diabetology, 4(1), 5.

5. He, K., Liu, K., Daviglus, M. L., Morris, S. J., Loria, C. M., Van Horn, L., ... \& Savage, P. J. (2006). Magnesium intake and incidence of metabolic syndrome among young adults. Circulation, 113(13), 1675-1682.

6. Xu, B., Sun, J., Deng, X., Huang, X., Sun, W., Xu, Y., ... \& Bi, Y. (2013). Low serum magnesium level is associated with microalbuminuria in Chinese diabetic patients. International journal of endocrinology, 2013.

7. Devin, T. M. (2010). Textbook of Biochemistry $6^{\text {th }}$ edn. John willey \& Sons Incorporated, 420-421. 
8. Song, Y., Manson, J. E., Buring, J. E., \& Liu, S. (2004). Dietary magnesium intake in relation to plasma insulin levels and risk of type 2 diabetes in women. Diabetes care, 27(1), 59-65.

9. Rodríguez-Morán, M., \& Guerrero-Romero, F. (2003). Oral magnesium supplementation improves insulin sensitivity and metabolic control in type 2 diabetic subjects: a randomized double-blind controlled trial. Diabetes care, 26(4), 1147-1152.

10. McCarty, M. F. (2005). Magnesium may mediate the favorable impact of whole grains on insulin sensitivity by acting as a mild calcium antagonist. Medical hypotheses, 64(3), 619-627.

11. Mandon, B. E. A. T. R. I. C. E., Siga, E., Chabardes, D., Firsov, D., Roinel, N., \& De Rouffignac, C. (1993). Insulin stimulates $\mathrm{Na}+, \mathrm{Cl}-$, $\mathrm{Ca} 2+$, and $\mathrm{Mg} 2+$ transports in $\mathrm{TAL}$ of mouse nephron: cross-potentiation with AVP. American Journal of Physiology-Renal Physiology, 265(3), F361-F369.

12. Hsu, C. C., Chang, H. Y., Huang, M. C., Hwang, S. J., Yang, Y. C., Tai, T. Y., ... \& Shin, S. J. (2011). Association between insulin resistance and development of microalbuminuria in type 2 diabetes: a prospective cohort study. Diabetes care, 34(4), 982-987.

13. Altura, B. T., \& Altura, B. M. (1987). Endothelium- dependent relaxation in coronary arteries requires magnesium ions. British journal of pharmacology, 91(3), 449-451.

14. Cunha, A. R., Umbelino, B., Correia, M. L., \& Neves, M. F. (2012). Magnesium and vascular changes in hypertension. International journal of hypertension, 2012. 